\title{
Nebulized epinephrine versus salbutamol for the management of children presenting with bronchiolitis: Single Center Study.
}

\footnotetext{
1. MBBS, FCPS (Peads)

Senior Registrar Pediatric Medicine PIMS Islamabad.

2. MBBS, FCPS (Peads)

Assistant Professor Pediatric Emergency Mayo Hospital, Lahore.

3. MBBS, FCPS Senior Registrar Pediatric Medicine King Edward Medical University Lahore.

4. MBBS, FCPS (Peads) Senior Registrar Pediatrics

5. MBBS, MD (Peads)

Senior Registrar Pediatric Medicine King Edward Medical University Lahore.

6. MBBS, FCPS (Peads) Assistant Professor Pediatric Emergency Mayo Hospital, Lahore. 7. MBBS, PGPN Medical Officer Pediatric Medicine General Hospital, Faisalabad.
}

\section{Correspondence Address:}

Dr. Muhammad Ahsan

Department of Pediatric Medicine General Hospital, Faisalabad. ahsanjahangir194@gmail.com

Article received on: 20/04/2020 Accepted for publication: 03/06/2020
Ana Farooq ${ }^{1}$, Tehmina Maqbool'2, Samia Aslam ${ }^{3}$, Mydah Tariq ${ }^{4}$, Muhammad Alam Khan ${ }^{5}$, Malik Abid Ali ${ }^{6}$, Muhammad Ahsan ${ }^{7}$

ABSTRACT... Objectives: To compare the outcome of nebulized epinephrine versus salbutamol for the management of children presenting with bronchiolitis. Study Design: Randomized Controlled Trial. Setting: Department of Pediatrics, Federal Government Polyclinic Hospital, Islamabad. Period: 6 month (1 ${ }^{\text {st }}$ October, 2016 to $1^{\text {st }}$ April, 2017). Material \& Methods: Children fulfilled selection criteria were enrolled. Then patients were randomly divided in two groups by using lottery method. In Group A, children received salbutamol. In group B, children received nebulized adrenaline. After 48 hours, children were evaluated for heart rate, respiratory rates, oxygen saturation and Respiratory Distress Assessment Index (RDAl) score. All the information was collected using proforma. Data was analyzed using SPSS version 21. Results: The mean age of children was $10.45 \pm 6.70$ months in epinephrine group and13.07 \pm 6.28 months in salbutamol group. There were 29 (52.7\%) males \& 26 (47.3\%) females in both groups. After 48 hours, mean heart rate was $122.58 \pm 4.75 \mathrm{bpm}$ with epinephrine while $127.87 \pm 4.4 .44 \mathrm{bpm}$ with salbutamol. Mean respiratory rate was $35.16 \pm 3.29 \mathrm{bpm}$ with epinephrine while $39.84 \pm 3.32 \mathrm{bpm}$ with salbutamol. Mean RDAl score was $8.35 \pm 1.36$ with epinephrine while $10.07 \pm 1.37$ with salbutamol. Mean oxygen saturation was $85.24 \pm 2.74 \%$ with epinephrine while $80.38 \pm 3.26 \%$ with salbutamol. The difference was significant $(P<0.05)$. Conclusion: Thus the nebulized epinephrine was found to be more effective in maintaining heart rate, respiratory rate, oxygen saturation and RDAI score of children as compared to salbutamol.

Key words: $\quad$ Bronchiolitis, Children, Heart Rate, Nebulized Epinephrine, Oxygen Saturation, Respiratory Rate, RDAI Score, Salbutamol.

Article Citation: Farooq A, Maqbool T, Aslam S, Tariq M, Khan MA, Ali MA, Ahsan M. Nebulized epinephrine versus salbutamol for the management of children presenting with bronchiolitis: Single Center Study. Professional Med J 2020; 27(12):2719-2728. https://doi.org/10.29309/TPMJ/2020.27.12.4726

\section{INTRODUCTION}

Acute viral bronchiolitis is one of the commonest lower respiratory tract infections in infants and younger children $<2$ years age. Most of the cases come in the winter and spring season. Within the first year of life, $10 \%$ of children are diagnosed with bronchiolitis. ${ }^{1}$ By age 2 , more than a third of children have had a bronchiolitis diagnosis. ${ }^{2}$ It is generally a self-limiting condition and is commonly associated with respiratory syncytial virus (RSV) infection. Human meta-pneumo virus can cause bronchiolitis almost similar to the disease caused by RSV. ${ }^{3}$

Pathophysiologically, bronchiolitis involves bronchiolar epithelium with profound sub mucosal edema, increased mucus secretion, peri bronchiolar mononuclear infiltration and epithelial cell necrosis. Cough, rhinitis, tachypnea, wheezing and respiratory distress are features of this disease. ${ }^{4}$ Various treatment strategies are in practice for years but no specific treatment for bronchiolitis is present. ${ }^{5}$

Nebulized epinephrine is safe for moderate to severe bronchiolitis and is better than salbutamol. ${ }^{6}$ Recently a study concluded that using epinephrine instead of salbutamol could be more effective in the management of the disease. This study showed that mean respiratory rate $(52.5 \pm 4.9$ vs. $50 \pm 2.9, P<0.05)$, oxygen saturation $(97.1 \pm 1.5$ vs. $97.9 \pm 0.8, P<0.05)$, mean heart rate $(151.8 \pm 10$ vs $160.2 \pm 10.2, P<0.05)$ and RDAl score $(6.4 \pm 1.7$ vs. $7.7 \pm 1.0, p>0.05)$ were 
significantly different in salbutamol and nebulized adrenaline therapy, respectively for management of bronchiolitis in children. ${ }^{7}$ But another trial concluded that nebulized epinephrine was not found to be more efficacious than albuterol in treating moderately ill infants with bronchiolitis. ${ }^{8}$

The rationale of our study was to compare outcome of nebulized epinephrine versus salbutamol for the management of children presenting with bronchiolitis. Literature has showed that nebulized ephedrine is more effective than salbutamol. But due to lack of local evidence, salbutamol is still in practice. It's not surprising that we lack the data for bronchiolitis and we have to rely heavily on the western data and base our treatments on that. To date, not a single study has been done from Pakistan evaluating the role of bronchodilators in bronchiolitis. This study will help change this scenario and provide clinical evidence regarding bronchodilator use in bronchiolitis treatment in Pakistani population. This technique being a cheap intervention has a cost saving benefit and this will help reduce the hospital stay.

\section{MATERIAL \& METHODS}

This randomized controlled trial was conducted in Department of Pediatrics, Federal Government Polyclinic Hospital (PGMI), Islamabad, after approval from the hospital ethical review committee. Children between 2-24 months of age, either gender diagnosed with bronchiolitis (as per operational definition) were included in the study. Bronchiolitis was defined as wheezing, respiratory rate $>50 \mathrm{bpm}$ from $2-12$ months of age and $>40$ bpm in 2 years children, with chest wall retractions, following an upper respiratory tract infection. Outcome was assessed after 48 hours of initial management of child as follows:

1. Heart Rate: in terms of number of heart beats per minute.

2. Respiratory Rate: in terms of number of breaths per minute.

3. Oxygen Saturation: in terms of measured via Pulse Oximetry (85 to $96 \%$ ).

4. RDAI Score: In terms of clinical score based on 2 variables of wheezing, respiratory rate and retractions
Null Hypothesis: There is no difference in the outcome of nebulized epinephrine versus salbutamol for the management of children presenting with bronchiolitis. Alternate Hypothesis: There is a difference in outcome of nebulized epinephrine versus salbutamol for the management of children presenting with bronchiolitis.

Exclusion criteria we used for this study was:

- Children with history of asthma or preexisting heart disease (known by medical record)

- Tachycardia $>180 / \mathrm{min}$, and respiratory rate $>100 /$ min.

- Already taken bronchodilator, glucocorticoids or monoamine oxidase inhibitors (medical record).

Sample size of 110 cases; 55 in each group (calculated with 95\% confidence level, 90\% power of study) with mean respiratory rate $52.5 \pm 4.9 \mathrm{rpm}$ with nebulized epinephrine and $50 \pm 2.9 \mathrm{rpm}$ with salbutamol for the management of children presenting with bronchiolitis. Patients were selected by non-probability, consecutive sampling. 110 children fulfilled selection criteria were enrolled in the study through emergency of Department of Pediatrics, Federal Government Polyclinic Hospital, Islamabad. Informed consent was obtained from parents. Demographic details (name, age, sex, weight of child, duration of bronchiolitis) were also obtained. Then patients were randomly divided in two groups by using lottery method.

In Group A, children received salbutamol (0.15 $\mathrm{mg} / \mathrm{kg}$ body weight) diluted in normal saline to make a total volume of $3 \mathrm{ml}$. In group $B$, children received nebulization with $0.1 \mathrm{ml} / \mathrm{kg}$ body weight of 1 in 10,000 solution of adrenaline (1 ampoule 1:1000 injection diluted with $9 \mathrm{ml}$ of normal saline). It was further mixed in normal saline making total of $3 \mathrm{ml}$, along with oxygen for five minutes at 0, 30, 60 minutes and then 4 hourly for 48 hours. After 48 hours, children were evaluated for heart rate, respiratory rates, oxygen saturation and RDAI score (as per operational definition). All the information was collected by the researcher herself by using proforma. 
Data was analyzed using SPSS version 21. Mean and Standard Deviation was calculated for quantitative variables like age, weight of child, duration of bronchiolitis, HR, RR, SpO2 and RDAI Score. Frequency and percentage was calculated for qualitative variables like gender. Both groups were compared for mean $\mathrm{HR}, \mathrm{RR}, \mathrm{SpO} 2$ and RDAI Score by using independent sample t-test. P-value $\leq 0.05$ was taken as significant. Confounders like age, gender, weight of child and duration of bronchiolitis was controlled through stratification. Post stratification, independent sample t-test was applied. P-value $\leq 0.05$ was taken as significant.

\section{RESULTS}

In epinephrine group, the mean age of children was $10.45 \pm 6.70$ months. In salbutamol group, the mean age of children was $13.07 \pm 6.28$ months. In epinephrine group, there were 29 (52.7\%) males \& 26 (47.3\%) females. In salbutamol group, there were $29(52.7 \%)$ males \& 26 (47.3\%) females.

In epinephrine group, the mean weight of children was $7.79 \pm 3.71 \mathrm{~kg}$. In salbutamol group, the mean weight of children was $9.18 \pm 3.45 \mathrm{~kg}$. In epinephrine group, mean duration of bronchiolitis was $3.98 \pm 2.12$ days. In salbutamol group, mean duration of bronchiolitis was $4.13 \pm 2.13$ days.

Table-I, shows the heart rates, respiratory rate, RDAl score and oxygen saturation in both the group. At baseline, the mean heart rate was $119.02 \pm 4.48 \mathrm{bpm}$ with epinephrine while $118.29 \pm 4.63 \mathrm{bpm}$ with salbutamol. The difference was insignificant $(P>0.05)$. After 48 hours, the mean heart rate was $122.58 \pm 4.75 \mathrm{bpm}$ with epinephrine while $127.87 \pm 4.4 .44 \mathrm{bpm}$ with salbutamol. $(P<0.05)$.

At baseline, the mean respiratory rate was $52.36 \pm 4.53 \mathrm{bpm}$ with epinephrine while $52.67 \pm 5.20 \mathrm{bpm}$ with salbutamol. The difference was insignificant $(P>0.05)$. After 48hours, the mean respiratory rate was $35.16 \pm 3.29 \mathrm{bpm}$ with epinephrine while $39.84 \pm 3.32 \mathrm{bpm}$ with salbutamol. $\quad(P<0.05)$. At baseline, the mean RDAl score was $12.02 \pm 2.26$ with epinephrine while $11.76 \pm 2.28$ with salbutamol. The difference was insignificant $(P>0.05)$. After 48hours, the mean RDAl score was $8.35 \pm 1.36$ with epinephrine while $10.07 \pm 1.37$ with salbutamol. $\quad(P<0.05)$.

At baseline, the mean oxygen saturation was $73.64 \pm 4.49 \%$ with epinephrine while $74.02 \pm 4.22 \%$ vwith salbutamol. The difference was insignificant $(P>0.05)$. After 48 hours, the mean oxygen saturation was $85.24 \pm 2.74 \%$ with epinephrine while $80.38 \pm 3.26 \%$ with salbutamol. $(P<0.05)$.

Data was stratified for age of patients. In age 2-12 months, after 48 hours, the mean heart rate was $123.26 \pm 4.32 \mathrm{bpm}$ with epinephrine while $127.52 \pm 4.33 \mathrm{bpm}$ with salbutamol. In age 1324 months, after 48 hours, the mean heart rate was $120.95 \pm 5.15 \mathrm{bpm}$ with epinephrine while $128.21 \pm 4.60 \mathrm{bpm}$ with salbutamol. $(P<0.05)$. Table-II

Data was stratified for age of children. In age $2-12$ months, after 48 hours, the mean respiratory rate was $35.32 \pm 3.60 \mathrm{bpm}$ with epinephrine while $40.26 \pm 3.34 \mathrm{bpm}$ with salbutamol. In age 13-24 months, after 48 hours, the mean respiratory rate was $34.90 \pm 2.77 \mathrm{bpm}$ with epinephrine while $39.43 \pm 3.32 \mathrm{bpm}$ with salbutamol. $(P<0.05)$.

Data was stratified for age of children. In age 2-12 months, after 48 hours, the mean RDAl score was $7.97 \pm 1.40$ with epinephrine while $9.89 \pm 1.34$ with salbutamol. In age 13-24 months, after 48 hours, the mean RDAl score was $8.95 \pm 1.07$ with epinephrine while $10.25 \pm 1.40$ with salbutamol. $(\mathrm{P}<0.05)$.

Data was stratified for age of patients. In age 2-12months, after 48 hours, the mean oxygen saturation was $85.41 \pm 2.97 \%$ with epinephrine while $79.74 \pm 3.46 \%$ with salbutamol. In age 1324 months, after 48 hours, the mean oxygen saturation was $84.95 \pm 2.38 \%$ with epinephrine while $81.00 \pm 2.99 \%$ with salbutamol. $(P<0.05)$.

Data was stratified for gender of patients. In males, after 48 hours, the mean heart rate was $123.38 \pm 5.11 \mathrm{bpm}$ with epinephrine while $128.66 \pm 4.49 \mathrm{bpm}$ with salbutamol. In 
females, after 48 hours, the mean heart rate was $121.27 \pm 4.12 \mathrm{bpm}$ with epinephrine while $127.00 \pm 4.30 \mathrm{bpm}$ with salbutamol. $(\mathrm{P}<0.05)$. Table-III

Data was stratified for gender of children. In males, after 48 hours, the mean respiratory rate was $35.59 \pm 3.42 \mathrm{bpm}$ with epinephrine while $39.93 \pm 3.41 \mathrm{bpm}$ with salbutamol. In females, after 48 hours, the mean respiratory rate was $34.69 \pm 3.13 \mathrm{bpm}$ with epinephrine while 39.73 $\pm 3.28 \mathrm{bpm}$ with salbutamol. $(\mathrm{P}<0.05)$.

Data was stratified for gender of children. In males, after 48 hours, the mean RDAl score was $7.86 \pm 1.38$ with epinephrine while $9.62 \pm 1.35$ with salbutamol. In females, after 48 hours, the mean RDAl score was $8.88 \pm 1.14$ with epinephrine while $10.58 \pm 1.24$ with salbutamol. $(P<0.05)$.

Data was stratified for gender of patients. In males, after 48 hours, the mean oxygen saturation was $84.97 \pm 3.03 \%$ with epinephrine while $80.83 \pm 3.47 \%$ with salbutamol. In females, after 48 hours, the mean oxygen saturation was $85.54 \pm 2.40 \%$ with epinephrine while $79.88 \pm 3.01 \%$ with salbutamol. $(P<0.05)$.

Data was stratified for weight of patients. In weight $2.5-8.0 \mathrm{~kg}$, after 48 hours, the mean heart rate was $123.16 \pm 4.10 \mathrm{bpm}$ with epinephrine while $127.4 \pm 4.47 \mathrm{bpm}$ with salbutamol. In weight $8.1-16.0 \mathrm{~kg}$, after 48 hours, the mean heart rate was $121.38 \pm 5.40 \mathrm{bpm}$ with epinephrine while $128.27 \pm 4.45 \mathrm{bpm}$ with salbutamol. $(\mathrm{P}<0.05)$. Table-IV

Data was stratified for weight of children. In weight $2.5-8.0 \mathrm{~kg}$, after 48 hours, the mean respiratory rate was $35.13 \pm 3.63 \mathrm{bpm}$ with epinephrine while $40.12 \pm 3.38 \mathrm{bpm}$ with salbutamol. In weight 8.1$16.0 \mathrm{~kg}$, after 48 hours, the mean respiratory rate was $35.21 \pm 2.86 \mathrm{bpm}$ with epinephrine while $39.6 \pm 3.31 \mathrm{bpm}$ with salbutamol. $(P<0.05)$.

Data was stratified for weight of children. In weight 2.5-8.0kg, after 48hours, the mean RDAl score was $7.97 \pm 1.45$ with epinephrine while $9.80 \pm 1.32$ with salbutamol. In weight $8.1-16.0 \mathrm{~kg}$, after 48 hours, the mean RDAI score was $8.83 \pm 1.09$ with epinephrine while $10.30 \pm 1.39$ with salbutamol. $(P<0.05)$.

Data was stratified for weight of patients. In weight $2.5-8.0 \mathrm{~kg}$, after 48 hours, the mean oxygen saturation was $85.35 \pm 2.97 \%$ with epinephrine while $79.80 \pm 3.40 \%$ with salbutamol. In weight $8.1-16.0 \mathrm{~kg}$, after 48 hours, the mean oxygen saturation was $85.08 \pm 2.47 \%$ with epinephrine while $80.87 \pm 3.12 \%$ with salbutamol. $(P<0.05)$.

Data was stratified for duration of patients. In duration 1-3 days, after 48 hours, the mean heart rate was $122.48 \pm 4.21 \mathrm{bpm}$ with epinephrine while $128.35 \pm 4.80 \mathrm{bpm}$ with salbutamol. In duration 4-7 days, after 48 hours, the mean heart rate was $122.31 \pm 5.17 \mathrm{bpm}$ with epinephrine while $127.53 \pm 4.20 \mathrm{bpm}$ with salbutamol. $(P<0.05)$. Table-V

Data was stratified for duration of children. In duration 1-3 days, after 48 hours, the mean respiratory rate was $35.43 \pm 3.60 \mathrm{bpm}$ with epinephrine while $40.30 \pm 3.52 \mathrm{bpm}$ with salbutamol. In duration 4-7 days, after 48 hours, the mean respiratory rate was $34.97 \pm 3.09 \mathrm{bpm}$ with epinephrine while $39.50 \pm 3.18 \mathrm{bpm}$ with salbutamol. $(P<0.05)$.

Data was stratified for duration of children. In duration 1-3 days, after 48 hours, the mean RDAl score was $8.30 \pm 1.33$ with epinephrine while 9.91 \pm 1.44 with salbutamol. In duration 4-7 days, after 48 hours, the mean RDAl score was $8.38 \pm 1.41$ with epinephrine while 10.19 \pm 1.33 with salbutamol. $(\mathrm{P}<0.05)$.

Data was stratified for duration of patients. In duration 1-3 days, after 48 hours, the mean oxygen saturation was $84.70 \pm 2.34 \%$ with epinephrine while $80.30 \pm 2.84 \%$ with salbutamol. In duration4-7days, after 48 hours, the mean oxygen saturation was $85.63 \pm 2.97 \%$ with epinephrine while $80.44 \pm 3.58 \%$ with salbutamol. $(\mathrm{P}<0.05)$. 


\begin{tabular}{|c|c|c|c|}
\hline \multirow{2}{*}{ Heart Rate } & \multicolumn{2}{|c|}{ Group } & \multirow{2}{*}{ P-Value } \\
\hline & Nebulized Epinephrine & Salbutamol & \\
\hline $\mathrm{N}$ & 55 & 55 & \\
\hline Baseline & $119.02 \pm 4.48$ & $118.29 \pm 4.63$ & 0.405 \\
\hline After 48 hours & $122.58 \pm 4.75$ & $127.87 \pm 4.4 .44$ & 0.000 \\
\hline \multirow{2}{*}{ Resp Rate } & \multicolumn{2}{|c|}{ Group } & \multirow{2}{*}{ P-Value } \\
\hline & Nebulized Epinephrine & Salbutamol & \\
\hline $\mathrm{N}$ & 55 & 55 & \\
\hline Baseline & $52.36 \pm 4.53$ & $52.67 \pm 5.20$ & 0.740 \\
\hline After 48 hours & $35.16 \pm 3.29$ & $39.84 \pm 3.32$ & 0.000 \\
\hline \multirow{2}{*}{ RDAI Score } & \multicolumn{2}{|c|}{ Group } & \multirow{2}{*}{ P-Value } \\
\hline & Nebulized Epinephrine & Salbutamol & \\
\hline $\mathrm{N}$ & 55 & 55 & \\
\hline Baseline & $12.02 \pm 2.26$ & $11.76 \pm 2.28$ & 0.557 \\
\hline After 48 hours & $8.35 \pm 1.36$ & $10.07 \pm 1.37$ & 0.000 \\
\hline \multirow{2}{*}{ Oxygen Saturation } & \multicolumn{2}{|c|}{ Group } & \multirow{2}{*}{ P-Value } \\
\hline & Nebulized Epinephrine & Salbutamol & \\
\hline $\mathrm{N}$ & 55 & 55 & \\
\hline Baseline & $73.64 \pm 4.49$ & $74.02 \pm 4.22$ & 0.647 \\
\hline After 48 hours & $85.24 \pm 2.74$ & $80.38 \pm 3.26$ & 0.000 \\
\hline
\end{tabular}

Table-I. Comparison of heart rate, resp rate, RDAI and Oxygen Saturation in both groups on follow-up $(n=110)$

\begin{tabular}{|c|c|c|c|c|}
\hline \multirow{2}{*}{ Age (Months) } & \multirow{2}{*}{ HR } & \multicolumn{2}{|c|}{ Group } & \multirow{2}{*}{ p-value } \\
\hline & & Nebulized Epinephrine & Salbutamol & \\
\hline \multirow{3}{*}{$2-12$} & $\mathrm{~N}$ & 34 & 27 & \\
\hline & Baseline & $118.68 \pm 4.52$ & $117.59 \pm 4.68$ & 0.364 \\
\hline & After 48 hours & $123.26 \pm 4.32$ & $127.52 \pm 4.33$ & 0.000 \\
\hline \multirow[t]{3}{*}{$13-24$} & $\mathrm{~N}$ & 21 & 28 & \\
\hline & Baseline & $119.57 \pm 4.47$ & $118.96 \pm 4.57$ & 0.645 \\
\hline & After 48 hours & $120.95 \pm 5.15$ & $128.21 \pm 4.60$ & 0.000 \\
\hline \multirow{2}{*}{ Age (Months) } & \multirow{2}{*}{ RDAI } & \multicolumn{2}{|c|}{ Group } & \multirow{2}{*}{$P$ value } \\
\hline & & Nebulized Epinephrine & Salbutamol & \\
\hline \multirow{3}{*}{$2-12$} & $\mathrm{~N}$ & 34 & 27 & \\
\hline & Baseline & $12.18 \pm 2.21$ & $12.30 \pm 2.13$ & 0.931 \\
\hline & After 48 hours & $7.97 \pm 1.40$ & $9.89 \pm 1.34$ & 0.000 \\
\hline \multirow{3}{*}{$13-24$} & $\mathrm{~N}$ & 21 & 28 & \\
\hline & Baseline & $11.76 \pm 2.36$ & $11.25 \pm 2.34$ & 0.454 \\
\hline & After 48 hours & $8.95 \pm 1.07$ & $10.25 \pm 1.40$ & 0.000 \\
\hline \multirow{2}{*}{ Age (Months) } & Oxygen & \multicolumn{2}{|c|}{ Group } & \multirow{2}{*}{$P$ value } \\
\hline & Saturation & Nebulized Epinephrine & Salbutamol & \\
\hline \multirow{3}{*}{$2-12$} & $\mathrm{~N}$ & 34 & 27 & \\
\hline & Baseline & $74.21 \pm 4.37$ & $74.41 \pm 4.29$ & 0.857 \\
\hline & After 48 hours & $85.41 \pm 2.97$ & $79.74 \pm 3.46$ & 0.000 \\
\hline \multirow{3}{*}{$13-24$} & $\mathrm{~N}$ & 21 & 28 & \\
\hline & Baseline & $72.71 \pm 4.65$ & $73.64 \pm 4.19$ & 0.468 \\
\hline & After 48 hours & $84.95 \pm 2.38$ & $81.00 \pm 2.99$ & 0.000 \\
\hline \multirow{2}{*}{ Age (Months) } & \multirow{2}{*}{ Resp Rate } & \multicolumn{2}{|c|}{ Group } & \multirow{2}{*}{ P-Value } \\
\hline & & Nebulized Epinephrine & Salbutamol & \\
\hline \multirow{3}{*}{$2-12$} & $\mathrm{~N}$ & 34 & 27 & \\
\hline & Baseline & $52.09 \pm 4.83$ & $52.19 \pm 5.35$ & 0.941 \\
\hline & After 48 hours & $35.32 \pm 3.60$ & $40.26 \pm 3.34$ & 0.000 \\
\hline \multirow{3}{*}{$13-24$} & $\mathrm{n}$ & 21 & 28 & \\
\hline & Baseline & $52.81 \pm 4.06$ & $53.14 \pm 5.10$ & 0.806 \\
\hline & After 48 hours & $34.90 \pm 2.77$ & $39.43 \pm 3.32$ & 0.000 \\
\hline
\end{tabular}




\begin{tabular}{|c|c|c|c|c|}
\hline \multirow{2}{*}{ Sex } & \multirow{2}{*}{ HR } & \multicolumn{2}{|c|}{ Group } & \multirow{2}{*}{ P-Value } \\
\hline & & Nebulized Epinephrine & Salbutamol & \\
\hline \multirow{3}{*}{ Male } & $\mathrm{N}$ & 29 & 29 & \\
\hline & Baseline & $118.9 \pm 4.61$ & $118.93 \pm 4.94$ & 0.978 \\
\hline & After 48 hours & $123.38 \pm 5.11$ & $128.66 \pm 4.49$ & 0.000 \\
\hline \multirow{3}{*}{ Female } & $\mathrm{N}$ & 26 & 26 & \\
\hline & Baseline & $119.15 \pm 4.42$ & $117.58 \pm 4.24$ & 0.196 \\
\hline & After 48 hours & $121.27 \pm 4.12$ & $127.00 \pm 4.30$ & 0.000 \\
\hline \multirow{2}{*}{ Sex } & \multirow{2}{*}{$\mathbf{R R}$} & \multicolumn{2}{|c|}{ Group } & \multirow{2}{*}{ P-Value } \\
\hline & & Neb Epinephrine & Salbutamol & \\
\hline \multirow{3}{*}{ Male } & $\mathrm{N}$ & 29 & 29 & \\
\hline & Baseline & $51.66 \pm 4.32$ & $51.9 \pm 5.80$ & 0.858 \\
\hline & After 48 hours & $35.59 \pm 3.42$ & $39.93 \pm 3.41$ & 0.000 \\
\hline \multirow{3}{*}{ Female } & $\mathrm{N}$ & 26 & 26 & \\
\hline & Baseline & $53.15 \pm 4.71$ & $53.54 \pm 4.38$ & 0.761 \\
\hline & After 48 hours & $34.69 \pm 3.13$ & $39.73 \pm 3.28$ & 0.000 \\
\hline \multirow{2}{*}{ Sex } & \multirow{2}{*}{ RDAl } & \multicolumn{2}{|c|}{ Group } & \multirow{2}{*}{ P-Value } \\
\hline & & Neb Epinephrine & Salbutamol & \\
\hline \multirow{3}{*}{ Male } & $\mathbf{N}$ & 29 & 29 & \\
\hline & Baseline & $12.34 \pm 2.08$ & $11.97 \pm 2.37$ & 0.519 \\
\hline & After 48 hours & $7.86 \pm 1.38$ & $9.62 \pm 1.35$ & 0.000 \\
\hline \multirow{3}{*}{ Female } & $\mathrm{N}$ & 26 & 26 & \\
\hline & Baseline & $11.65 \pm 2.43$ & $11.54 \pm 2.20$ & 0.858 \\
\hline & After 48 hours & $8.88 \pm 1.14$ & $10.58 \pm 1.24$ & 0.000 \\
\hline \multirow{2}{*}{ Sex } & \multirow{2}{*}{ Oxygen Saturation } & \multicolumn{2}{|c|}{ Group } & \multirow{2}{*}{ P-Value } \\
\hline & & Nebulized Epinephrine & Salbutamol & \\
\hline \multirow{3}{*}{ Male } & $\mathrm{N}$ & 29 & 29 & \\
\hline & Baseline & $73.14 \pm 4.58$ & $74.14 \pm 4.64$ & 0.412 \\
\hline & After 48 hours & $84.97 \pm 3.03$ & $80.83 \pm 3.47$ & 0.000 \\
\hline \multirow{3}{*}{ Female } & $\mathrm{N}$ & 26 & 26 & \\
\hline & Baseline & $74.19 \pm 4.42$ & $73.88 \pm 3.78$ & 0.788 \\
\hline & After 48 hours & $85.54 \pm 2.40$ & $79.88 \pm 3.01$ & 0.000 \\
\hline
\end{tabular}




\begin{tabular}{|c|c|c|c|c|}
\hline \multirow{2}{*}{ Weight (kg) } & \multirow{2}{*}{ HR } & \multicolumn{2}{|c|}{ Group } & \multirow{2}{*}{ P-Value } \\
\hline & & Neb Epinephrine & Salbutamol & \\
\hline \multirow{3}{*}{$2.5-8.0$} & $\mathrm{n}$ & 31 & 25 & \\
\hline & Baseline & $118.26 \pm 4.43$ & $117.72 \pm 4.84$ & 0.666 \\
\hline & After 48 hours & $123.16 \pm 4.10$ & $127.4 \pm 4.47$ & 0.001 \\
\hline \multirow{3}{*}{$8.1-16.0$} & $\mathrm{n}$ & 24 & 30 & \\
\hline & Baseline & $120.00 \pm 4.44$ & $118.7 \pm 4.49$ & 0.318 \\
\hline & After 48 hours & $121.38 \pm 5.40$ & $128.27 \pm 4.45$ & 0.000 \\
\hline \multirow{2}{*}{ Weight } & \multirow{2}{*}{$\mathbf{R R}$} & \multicolumn{2}{|c|}{ Group } & \multirow{2}{*}{ P-Value } \\
\hline & & Nebulized Epinephrine & Salbutamol & \\
\hline \multirow{3}{*}{$2.5-8.0$} & $\mathrm{n}$ & 31 & 25 & \\
\hline & Baseline & $52.48 \pm 4.84$ & $52.12 \pm 5.18$ & 0.787 \\
\hline & After 48 hours & $35.13 \pm 3.63$ & $40.12 \pm 3.38$ & 0.000 \\
\hline \multirow{3}{*}{$8.1-16.0$} & $\mathrm{n}$ & 24 & 30 & \\
\hline & Baseline & $52.21 \pm 4.19$ & $53.13 \pm 5.25$ & 0.486 \\
\hline & After 48 hours & $35.21 \pm 2.86$ & $39.6 \pm 3.31$ & 0.000 \\
\hline \multirow{2}{*}{ Weight } & \multirow{2}{*}{ RDAl } & \multicolumn{2}{|c|}{ Group } & \multirow{2}{*}{ P-Value } \\
\hline & & Nebulized Epinephrine & Salbutamol & \\
\hline \multirow{3}{*}{$2.5-8.0$} & $\mathrm{n}$ & 31 & 25 & \\
\hline & Baseline & $12.29 \pm 2.15$ & $12.32 \pm 2.04$ & 0.958 \\
\hline & After 48 hours & $7.97 \pm 1.45$ & $9.80 \pm 1.32$ & 0.000 \\
\hline \multirow{3}{*}{$8.1-16.0$} & $\mathrm{n}$ & 24 & 30 & \\
\hline & Baseline & $11.67 \pm 2.39$ & $11.30 \pm 2.40$ & 0.578 \\
\hline & After 48 hours & $8.83 \pm 1.09$ & $10.30 \pm 1.39$ & 0.000 \\
\hline \multirow{2}{*}{ Weight } & \multirow{2}{*}{ Oxygen Saturation } & \multicolumn{2}{|c|}{ Group } & \multirow{2}{*}{ P-Value } \\
\hline & & Nebulized Epinephrine & Salbutamol & \\
\hline \multirow{3}{*}{$2.5-8.0$} & $\mathrm{n}$ & 31 & 25 & \\
\hline & Baseline & $74.42 \pm 4.08$ & $74.64 \pm 4.32$ & 0.845 \\
\hline & After 48 hours & $85.35 \pm 2.97$ & $79.80 \pm 3.40$ & 0.000 \\
\hline \multirow{3}{*}{$8.1-16.0$} & $\mathrm{n}$ & 24 & 30 & \\
\hline & Baseline & $72.63 \pm 4.88$ & $73.5 \pm 4.13$ & 0.479 \\
\hline & After 48 hours & $85.08 \pm 2.47$ & $80.87 \pm 3.12$ & 0.000 \\
\hline
\end{tabular}




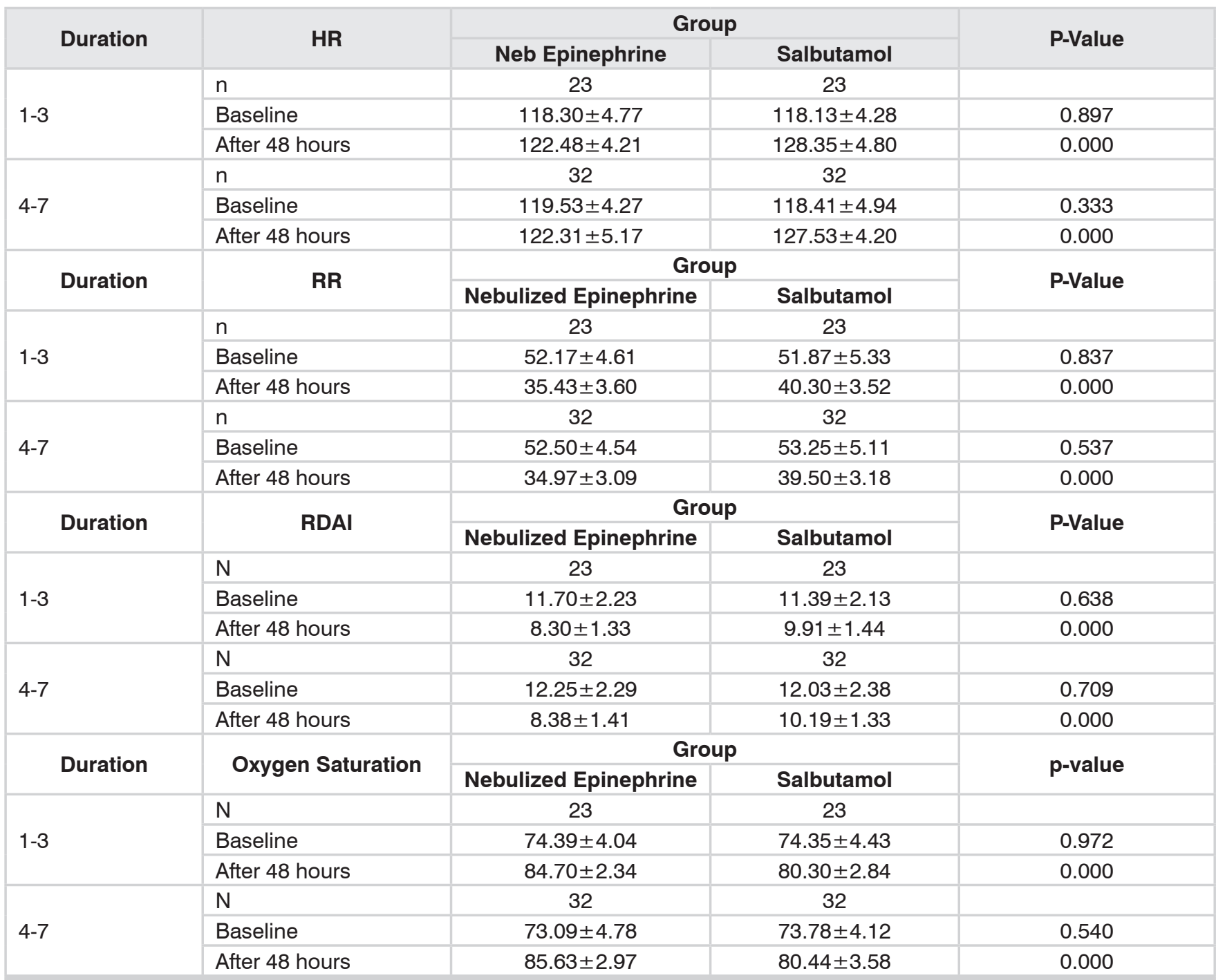

Table-V. Comparison of heart rate in both groups on follow-up stratified for duration $(n=110)$

\section{DISCUSSION}

Despite widespread use of inhaled $\beta 2$-agonists for bronchodilation in infants with bronchiolitis since the late 1950s, the efficacy of these drugs remains unproven. In 1978, Wohl and Chernick suggested that epinephrine, a combined $a$-and $\beta$-receptor agonist, would be an ideal bronchodilator. ${ }^{8}$

In our study, at baseline, the mean heart rate was $119.02 \pm 4.48 \mathrm{bpm}$ which was reduced to $122.58 \pm 4.75 \mathrm{bpm}$ with epinephrine while $118.29 \pm 4.63 \mathrm{bpm}$ with salbutamol which was reduced to $127.87 \pm 4.4 .44 \mathrm{bpm}$. The difference was significant $(P<0.05)$ between both groups. In our study, at baseline, the mean respiratory rate was $52.36 \pm 4.53 \mathrm{bpm}$ with epinephrine which was reduced to $35.16 \pm 3.29 \mathrm{bpm}$ while $52.67 \pm 5.20 \mathrm{bpm}$ with salbutamol which was reduced to $39.84 \pm 3.32 \mathrm{bpm}$. The difference was significant $(P<0.05)$.

In our study, at baseline, the mean RDAl score was 12.02 \pm 2.26 with epinephrine which was reduced to $8.35 \pm 1.36$ while $11.76 \pm 2.28$ with salbutamol which was reduced to $10.07 \pm 1.37$ with salbutamol. The difference was significant $(P<0.05)$. In our study, at baseline, the mean oxygen saturation was $73.64 \pm 4.49 \%$ with epinephrine which was reduced to $85.24 \pm 2.74 \%$ while $74.02 \pm 4.22 \%$ with salbutamol which was reduced to $80.38 \pm 3.26 \%$ with salbutamol. The difference was significant $(P<0.05)$. 
Nebulized epinephrine is a useful and safe drug for moderate/severe bronchiolitis and is superior to salbutamol. ${ }^{6}$ In a study it was concluded that using epinephrine instead of salbutamol could be more effective in the management of the disease. This study showed that mean respiratory rate (52.5 \pm 4.9 vs. $50 \pm 2.9, P<0.05)$, oxygen saturation $(97.1 \pm 1.5$ vs. $97.9 \pm 0.8, P<0.05)$, mean heart rate $(151.8 \pm 10$ vs $160.2 \pm 10.2, P<0.05)$ and RDAl score (6.4 \pm 1.7 vs. $7.7 \pm 1.0, p>0.05)$ were significantly different in salbutamol and nebulized adrenaline therapy, respectively for management of bronchiolitis in children. ${ }^{7}$ But another trial concluded that nebulized epinephrine was not found to be more efficacious than albuterol in treating moderately ill infants with bronchiolitis. ${ }^{8}$

Adhikari et al., reported that mean respiratory rate $(37.0 \pm 6.0$ vs. $36.0 \pm 5.0)$ and RDAl score $(4.15 \pm 1.82$ vs. $4.1 \pm 1.36)$ were significantly different in salbutamol and nebulized adrenaline therapy, respectively for management of bronchiolitis in children. ${ }^{9}$

Modaressi et al., also reported that mean RDAl after 48 hours was $4.3 \pm 2.6$ with salbutamol while $3.1 \pm 2.2$ with epinephrine. The difference was significant $(p=0.02) .{ }^{10}$ But a study by John et al., showed that mean heart rate $(161.71 \pm 14.38 \mathrm{vs}$. $160.29 \pm 12.86, \quad p=0.29)$, oxygen saturation (88.86 \pm 2.66 vs. $88.93 \pm 2.59, P=0.08)$, mean respiratory rate $(85.14 \pm 7.43 \mathrm{vs} 84.14 \pm 6.19$, $\mathrm{P}=0.41)$ and RDAl score (12.92 $\pm 0.99 \mathrm{vs}$. $12.79 \pm 0.98, p=0.29)$ were significantly different in nebulized epinephrine and salbutamol, respectively for management of bronchiolitis in children and nebulized epinephrine showed better results than salbutamol.

In a systematic review, it was concluded that salbutamol had no effect on bronchiolitis in children less than 2 years old. And its use before this age can lead to adverse effects, such as high heart rate. ${ }^{11}$

Similarly, studies have shown that the nebulized epinephrine is also not safe for routine use in infants with bronchiolitis. It should be considered in severe symptoms only. If it is given and there are no signs of improvement, further doses are discouraged. Further trials should be done along with other agents (eg, hypertonic saline, oral dexamethasone) to confirm their benefits. ${ }^{12}$

Nebulized epinephrine was found to be more effective in maintaining heart rate, respiratory rate, oxygen saturation and RDAl score of children as compared to salbutamol. Further trials are required comparing the two drugs.

\section{CONCLUSION}

The nebulized epinephrine was found to be more effective in maintaining heart rate, respiratory rate, oxygen saturation and RDAl score of children as compared to salbutamol. This shows that nebulization using epinephrine with proper technique can be used in the treatment of children with bronchiolitis. Further trials are required comparing the two drugs.

\section{LIMITATION OF THE STUDY}

The limitations of this study included a small sample size done at a single center without taking in some factors like nutritional status, socioeconomic status. Long term side effects or adverse effects were not documented as well during or after the trial. These factors should be considered in other trials.

Copyright $(0) 03$ June, 2020.

\section{REFERENCES}

1. Ducharme FM. Management of acute bronchiolitis. BMJ 2011; 342:d1658.

2. Zorc JJ, Hall CB. Bronchiolitis: Recent evidence on diagnosis and management. Pediatrics 2010; 125(2):342-9.

3. Flores $\mathrm{P}$, Mendes AL, Neto AS. A randomized trial of nebulized $3 \%$ hypertonic saline with salbutamol in the treatment of acute bronchiolitis in hospitalized infants. Pediatr Pulmonol. 2016; 51(4):418-425.

4. Borchers AT, Chang C, Gershwin ME, Gershwin LJ. Respiratory syncytial virus-a comprehensive review. Clinical reviews in allergy \& immunology 2013; 45(3):331-79.

5. Bourke TW, Shields MD. Bronchiolitis. BMJ Clin Evid $2011 ; 4: 308$. 
6. John B, Patnaik S, Prasad P. Efficacy of nebulized epinephrine versus salbutamol in hospitalized children with bronchiolitis. Medical Journal Armed Forces India 2006; 62(4):354-7.

7. Morshed AA, Amin MR. Comparative efficacy of nebulized I-adrenaline versus salbutamol in infants with acute bronchiolitis. Bangladesh Journal of Child Health 2008; 32(1):10-6.

8. Mull CC, Scarfone RJ, Ferri LR, Carlin T, Salvaggio C, Bechtel KA, et al. A randomized trial of nebulized epinephrine vs albuterol in the emergency department treatment of bronchiolitis. Archives of pediatrics \& adolescent medicine 2004; 158(2):113-8.
9. Adhikari S, Thapa P, Rao K, Bk G. Comparison of initial response of nebulized salbutamol and adrenaline in infants and young children admitted with acute bronchiolitis. Kathmandu Univ Med J 2016; 53(1):31-5.

10. Modaressi M-R, Asadian A, Faghihinia J, Arashpour M, Mousavinasab F. Comparison of epinephrine to salbutamol in acute bronchiolitis. Iranian journal of pediatrics 2012; 22(2):241.

11. Cai Z, Lin Y, Liang J. Efficacy of salbutamol in the treatment of infants with bronchiolitis: A metaanalysis of 13 studies. Medicine (Baltimore). 2020; 99(4):e18657.

12. Sakulchit T, Goldman RD. Nebulized epinephrine for young children with bronchiolitis. Can Fam Physician. 2016; 62(12):991-993.

\section{AUTHORSHIP AND CONTRIBUTION DECLARATION}

\begin{tabular}{|c|l|l|l|}
\hline Sr. \# & \multicolumn{1}{|c|}{ Author(s) Full Name } & \multicolumn{1}{|c|}{ Contribution to the paper } & Author(s) Signature \\
\hline 1 & Ana Farooq & Data collection, Data entry. \\
2 & Tehmina Maqbool & Data analysis \& entry. \\
3 & Samia Aslam & $\begin{array}{l}\text { Data analysis, Discussion } \\
\text { wirting. } \\
4\end{array}$ & Maper writing, Data analysis. \\
5 & M. Alam Khan & Data entry, Data analysis. \\
6 & Malik Abid Ali & Discussion writing. \\
7 & Muhammad Ahsan & Paper writing, Data analysis.
\end{tabular}

